\title{
Two new species of Stillabothrium (Cestoda: Rhinebothriidea) from stingrays of the genus Fontitrygon from Senegal
}

\author{
Elsie A. Dedrick ${ }^{1}$, Florian B. Reyda ${ }^{1}$, Elise K. Iwanyckyj ${ }^{1}$, Timothy R. Ruhnke ${ }^{2}$ \\ ${ }^{1}$ Biology Department \& Biological Field Station, State University of New York, College at Oneonta, Ravine Parkway Oneonta, NY, USA; \\ ${ }^{2}$ Department of Biology, West Virginia State University, Institute, WV, USA
}

\begin{abstract}
Morphological and molecular analyses of cestode specimens collected during survey work of batoid elasmobranchs and their parasites in Senegal revealed two new species of the rhinebothriidean cestode genus Stillabothrium Healy et Reyda 2016. Stillabothrium allisonae Dedrick et Reyda sp. n. and Stillabothrium charlotteae Iwanyckyj, Dedrick et Reyda sp. n. are both described from Fontitrygon margaritella (Compagno et Roberts) and Fontitrygon margarita (Günther). Both new cestode species overlap in geographic distribution, host use and proglottid morphology, but are distinguished from each other, and from the other seven described species of Stillabothrium, on the basis of their pattern of bothridial loculi. Phylogenetic analyses based on sequence data for 1,084 bp from the D1-D3 region of 28S rDNA that included multiple specimens of both new species and eight other species of Stillabothrium corroborated the morphologically-determined species boundaries. The phylogenetic analyses indicate that S. allisonae sp. n. and S. charlotteae sp. n. are sister species, a noteworthy pattern given that the two species of the stingray genus Fontitrygon they both parasitise, F. margaritella and F. margarita, are also sister species. Although species of Stillabothrium vary widely in their patterns of facial loculi, the variation does not appear to correlate with phylogeny. Most species of Stillabothrium parasitise myliobatiform elasmobranch genera of the Dasyatidae Jordan. This study brings the number of described species of Stillabothrium to nine, three of which occur in the eastern Atlantic, two of which occur off the northern coast of Australia, and four of which are from coastal Borneo.
\end{abstract}

Keywords: tapeworms, taxonomy, 28S rDNA, phylogeny, survey, sister species, biodiversity, species boundaries

Our understanding of the species diversity of many orders of cestodes has expanded substantially in recent years owing to a global effort by an international team of scientists to survey, inventory and describe new species. This progress was recently summarised in a volume edited by Caira and Jensen (2017) in which taxonomic and systematic information on each of the 19 cestode orders is provided by the experts of the respective orders. As part of this effort, the generic and species diversity the cestode order Rhinebothriidea Healy, Caira, Jensen, Webster et Littlewood, 2009 has been substantially expanded since its establishment in 2009 (Healy et al. 2009) to accommodate newly discovered taxa with unique scolex morphologies.

Four of the rhinebothriidean genera originally referred to by Healy et al. (2009) as potentially new, based on both morphological and molecular data, were subsequently described in two studies (Reyda et al. 2016, Caira et al. 2017). These genera are Stillabothrium Healy et Reyda, 2016, with seven species, Barbeaucestus Caira, Healy, Marques et Jensen, 2017 with four species, Divaricobothrium Caira, Healy, Marques et Jensen, 2017 with two species, and Sungaicestus Caira, Healy, Marques et Jensen, 2017 with a single species. Except for Sungaicestus, each of these genera is potentially more diverse; in both studies (Reyda et al. 2016, Caira et al. 2017) the authors referred to specimens of additional undescribed species of the new genera.

This paper focuses on two previously undescribed species of Stillabothrium that were obtained during field work on the coast of Senegal in 2003, 2004 and 2005, and referred to in the study by Healy et al. (2009) as Rhinebothriinae New genus 3 sp. n. 1 and Rhinebothriinae New genus 3 sp. n. 2 (or simply New genus 3 sp. n. 1 and New genus 3 sp. n. 2). The two new species described in this study overlap in geographic distribution and in host use. Both species were found in the spiral intestines of Fontitrygon margarita (Günther) and Fontitrygon margaritella (Compagno et Roberts) and there were several instances of concurrent infections. In this study, as in the one by Reyda et al. (2016), morphological data were complemented by sequence data for the D1-D3 region of the 28S rDNA gene. Both sources of data played a key role in delineating the boundaries of the new species in the context of a phylogeny of species of Stillabothrium. 


\section{MATERIALS AND METHODS}

The cestodes described here came from two individuals of Fontitrygon margarita (Collection Code and Numbers SE-232 and SE-241) and eight individuals of Fontitrygon margaritella (Collection Code and Numbers SE-125, SE-228, SE-229, SE233, SE-262, SE-279, SE-306 and SE-308). The stingray specimens were collected from the coast of Senegal during field work that occurred in 2003, 2004 and 2005. Stingrays were collected in conjunction with local fishermen. Each host was identified in the field, assigned a Collection Code and unique Collection Number, and photographed, and relevant information (e.g. sex, size) was recorded. A tissue sample was also collected for subsequent DNA analysis. Additional data for each host specimen can be accessed at the Global Cestode Database (Caira et al. 2012) at www.elasmobranchs.tapewormdb.uconn.edu by entering its assigned Collection Code and Collection Number (e.g. SE-232). Elasmobranch classification follows Naylor et al. (2012a); elasmobranch taxonomy follows Last et al. (2016). Field identifications of host specimens were verified using NADH2 sequence data (see Naylor et al. 2012b).

In the case of each host specimen, the spiral intestine was removed and opened with a longitudinal incision. A subsample of worms was removed, washed in seawater and sorted into two subsets. The first subset was fixed in 10\% seawater-buffered formalin and subsequently stored in $70 \%$ ethanol; the other subset was fixed in $95 \%$ ethanol. Spiral intestines were fixed in $10 \%$ seawater-buffered formalin and additional worms were removed under a dissecting microscope upon return to the laboratory. Worms prepared as whole mounts were hydrated in a graded series of ethanols, stained in Delafield's hematoxylin, destained in $70 \%$ acid ethanol, neutralised in $70 \%$ basic ethanol, dehydrated in a graded ethanol series, cleared in methyl salicylate, and mounted on glass slides in Canada balsam. Worms examined with SEM (scanning electron microscopy) were cut in half and the strobila of each was prepared as a whole mount as described above to serve as a voucher, and the scolex was examined with SEM. Scoleces were hydrated in a graded ethanol series, placed in $1 \%$ osmium tetroxide overnight, dehydrated in a graded ethanol series, transferred to hexamethyldisilazane for $15 \mathrm{~min}$ in an exhaust hood and allowed to air dry. Dried worms were mounted on carbon tabs (Ted Pella, Inc., Redding, California) on aluminium stubs, placed in a dessicator overnight, sputter coated with 250-300 A of gold/palladium and examined with a LEO/Zeiss DSM982 Gemini or FEI Nova Nano 450 (University of Connecticut) field emission scanning electron microscope (FESEM). Microthrix terminology follows Chervy (2009).

Measurements of whole mounted cestodes were obtained using an ocular micrometre on an Olympus CX31 compound microscope, or taken with the aid of LAS V3.8 (Leica Application Suite, Leica microsystems, Switzerland) digital microscopy software connected to a Leica DSC295 digital camera on a Leica DM2500 compound microscope. All measurements are reported in micrometres unless otherwise stated, and are presented in descriptions as the range followed in parentheses by the mean, standard deviation and number of worms measured. Scolex morphological shape terminology follows Clopton (2004). Drawings were made with the aid of a drawing tube. Museum abbreviations are as follows: IPCAS, Institute of Parasitology of the Biology Centre of the Czech Academy of Science, České Budějovice,
Czech Republic; LRP, Lawrence R. Penner Parasitology Collection, Department of Ecology \& Evolutionary Biology, University of Connecticut, Storrs, Connecticut, U.S.A.; MNHN, Muséum National d'Histoire Naturelle, Paris, France; USNM, United States National Museum, Smithsonian Institution, Washington, D.C. U.S.A. Nomenclatural acts in this manuscript are registered at Zoobank.org.

The molecular analyses included newly sequenced specimens and sequences from GenBank that were generated for previous studies (Healy et al. 2009, Reyda et al. 2016). All newly sequenced specimens originally fixed in $95 \%$ were initially cut and either the scolex and/or terminal proglottid was removed and prepared as whole mounts as described above, and deposited in the LRP as hologenophores, The remaining portion of each specimen was subjected to the molecular protocols mentioned below.

Table 1 provides taxon name, host, collection locality, museum accession number for hologenophores (sensu Pleijel et al. 2008) and GenBank accession numbers for each of the specimens included in the molecular analyses. Sequence data were generated for two or more individuals of both new species of Stillabothrium and included in the molecular analysis, given that the goal was to test species boundaries of the new species within the context of a phylogenetic hypothesis of members of the genus Stillabothrium. Sequence data obtained from GenBank for the analysis consisted of a single sequence for each of the seven described species of Stillabothrium as well as for a specimen of an undescribed species, referred to as Stillabothrium sp. n. 4 by Reyda et al. (2016). Protocols for DNA extraction, PCR amplification, DNA sequencing, sequence analysis and sequence alignment are as given in Reyda et al. (2016).

Phylogenetic analysis was conducted on sequences of a total of 19 specimens of 12 cestode species (Table 1). Anthocephalum michaeli Ruhnke et Seaman, 2009 and Escherbothrium sp. were used as outgroup species. Bayesian inference was conducted using MrBayes version 3.2 (Ronquist and Huelsenbeck 2003) with the following settings: 1set nst $=6$ rates $=$ invgamma ngammacat $=4$; ngen $=5,000,000$; samplefreq $=1,000$. Fifty percent of the samples were discarded on burnin. Bootstrap analysis was also conducted using PAUP* verion 5.4.0b (Swofford 2000). One thousand replicates $(1,000)$ were performed, with ten step-wise addition heuristic searches per replicate.

\section{RESULTS}

\section{Phylogenetic analyses}

The topology of the tree resulting from the Bayesian analysis of the sequence data is given in Fig. 1. The ten species of Stillabothrium that were analysed in this study grouped in two principle clades that correspond to the clades termed Clade 1 and Clade 2 by Reyda et al. (2016). Clade 1 and Clade 2 each consist of five species of Stillabothrium. Clade 1 consists of Stillabothrium allisonae sp. n., Stillabothrium charlotteae sp. n., Stillabothrium jeanfortiae Forti, Aprill et Reyda, 2016, Stillabothrium cadenati (Euzet, 1954) Healy et Reyda, 2016 and the undescribed species referred to as Stillabothrium sp. n. 4 (see Fig. 1). Four of these five species conspicuously lack marginal loculi on the bothridia, a feature that is a characteristic of $S$. charlotteae sp. n. Clade 2 membership con- 


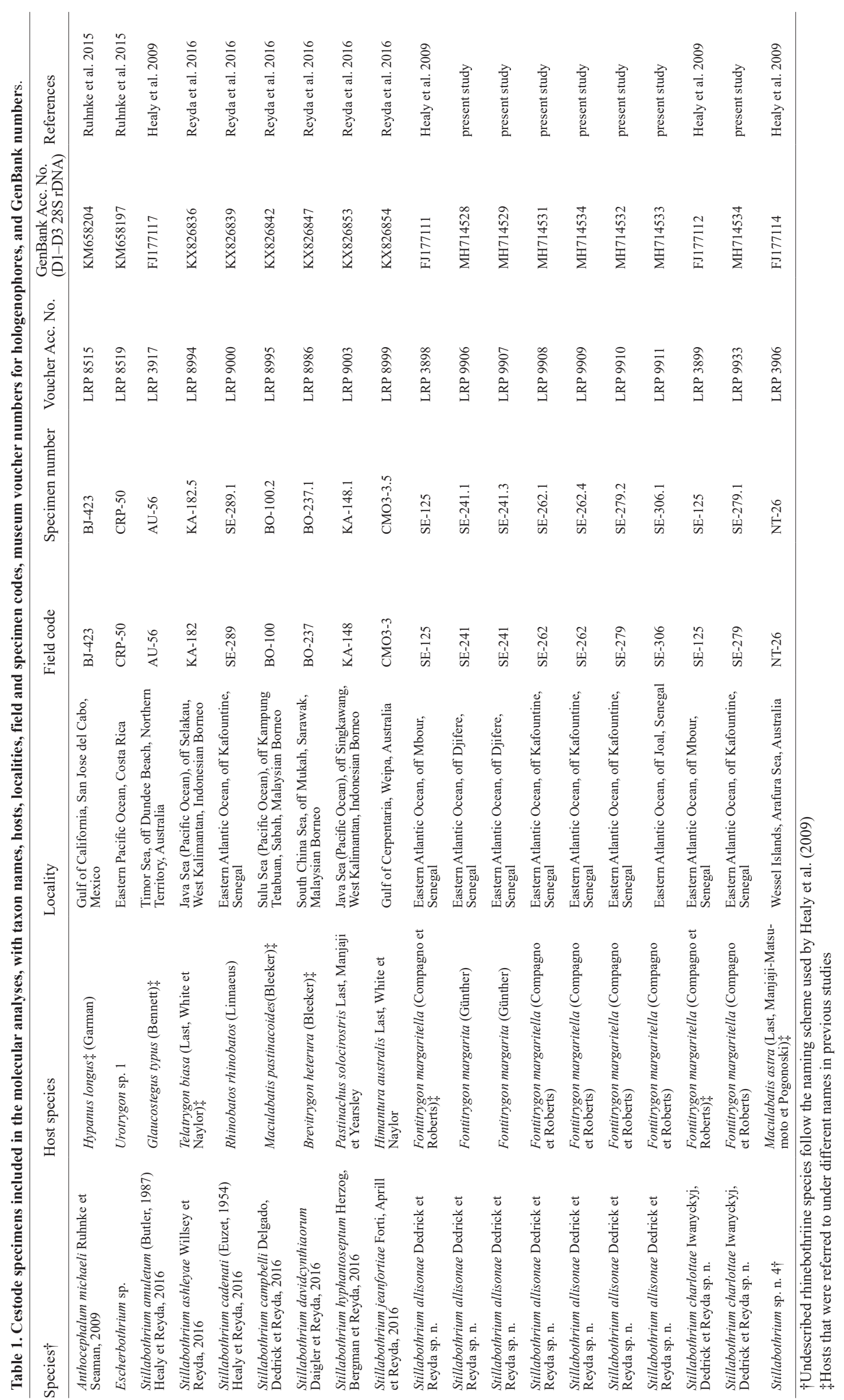




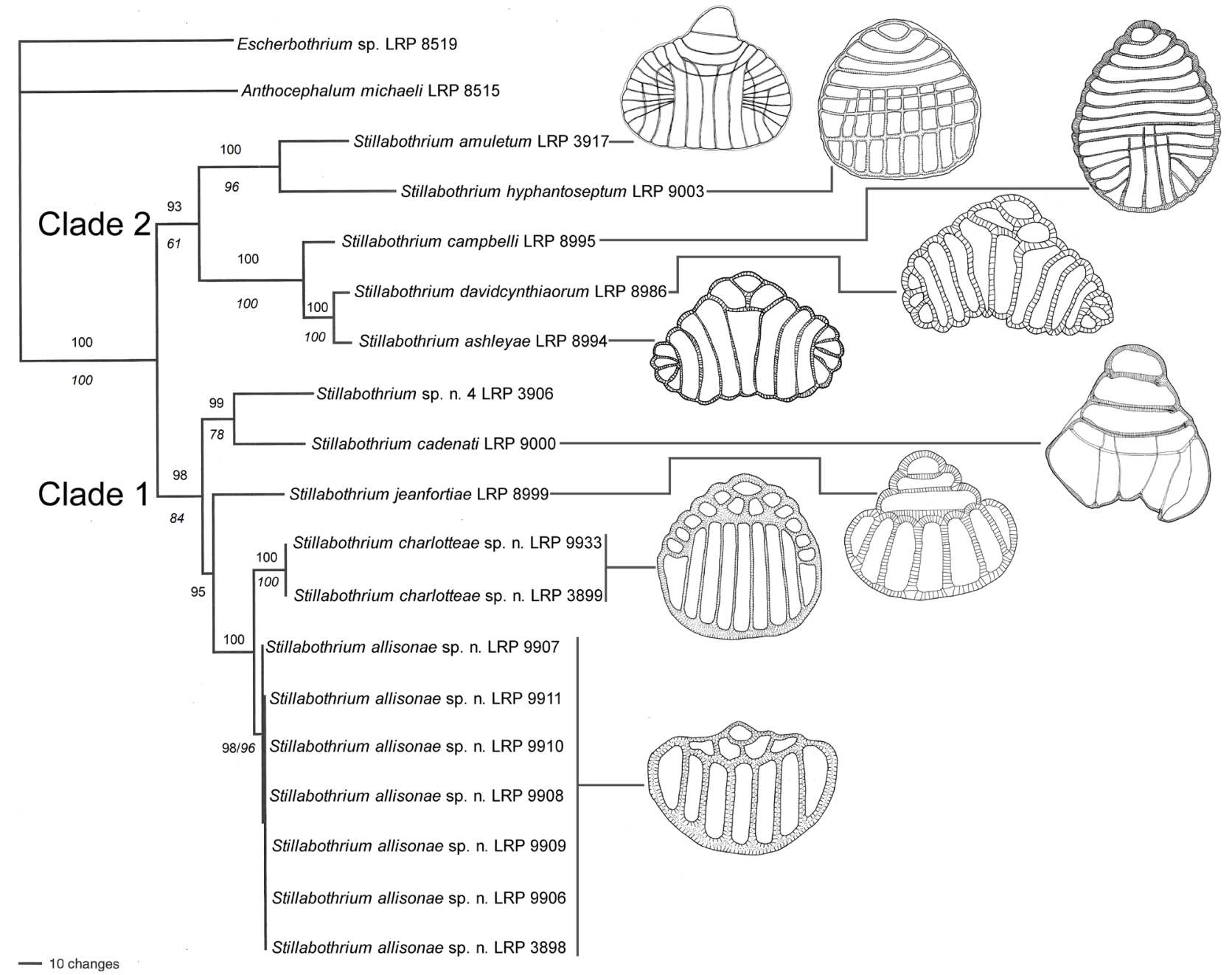

Fig. 1. Phylogram based on Bayesian analysis of a 1,084 bp region of D1-D3 28S rDNA. Numbers above branches indicate Bayesian posterior probabilities, numbers below indicate bootstrap percentage values based on 1,000 replicates. Scale indicates expected number of substitutions per site. Diagrammatic line drawings of fully opened bothridia of the nine described species are shown representing those respective species. Host species information in Table 1.

sists of Stillabothrium ashleyae Willsey et Reyda, 2016, Stillabothrium davidcynthiaorum Daigler et Reyda, 2016, Stillabothrium campbelli Delgado, Dedrick et Reyda, 2016, Stillabothrium hyphantoseptum Herzog, Bergman et Reyda, 2016, and Stillabothrium amuletum (Butler, 1987) Healy et Reyda, 2016. Three of the five species in Clade 2, S. amuletum, S. hyphantoseptum, and S. campbelli, possess septa that conspicuously overlap one another, a feature lacking in the other two species, S. ashleyae and S. davidcynthiaorum.

The monophyly of replicate specimens of both new species of Stillabothrium was found as a result of the Bayesian analysis. This arrangement was strongly supported with Bayesian posterior probabilities and with bootstrap analysis. The topology observed within the seven individuals of the $S$. allisonae clade did not correspond to host use. Six of the seven specimens, including one from Fontitrygon margarita (LRP 9906) and five from Fontitrygon margaritella (LRP Nos. 3898, 9908-9911), had identical sequences whereas the seventh specimen, LRP 9907 from F. margarita, differed from the others by $1 \mathrm{bp}$. The two specimens of $S$. charlotteae sp. n. that analysed were from two different individuals of $F$. margaritella and were identical in sequence for the D1-D3 region of 28S rDNA gene.

\section{Descriptions}

Stillabothrium allisonae Dedrick et Reyda sp. n. Figs. 1-3

ZooBank number for species:

urn:Isid:zoobank.org:act:D805E908-579C-4A2F-9095-C7AE24EF3BC6

Description (based on whole mounts of 17 complete mature worms and 3 scoleces prepared for SEM): Worms (Fig. 2A) euapolytic, acraspedote, $1.37-3.11 \mathrm{~mm}(2.16$ $\pm 0.48 ; \mathrm{n}=17)$ long, greatest width $330-639(457 \pm 94$; $\mathrm{n}=17)$ at level of scolex; $6-12(9.4 \pm 2 ; n=17)$ proglottids per worm. Cephalic peduncle lacking; darkly staining germinative zone present.

Scolex (Fig. 2B) consisting of scolex proper bearing four stalked bothridia. Stalks 50-125 $(82 \pm 21 ; \mathrm{n}=16)$ long by $40-75(54 \pm 10 ; n=16)$ wide, attached slightly posteri- 


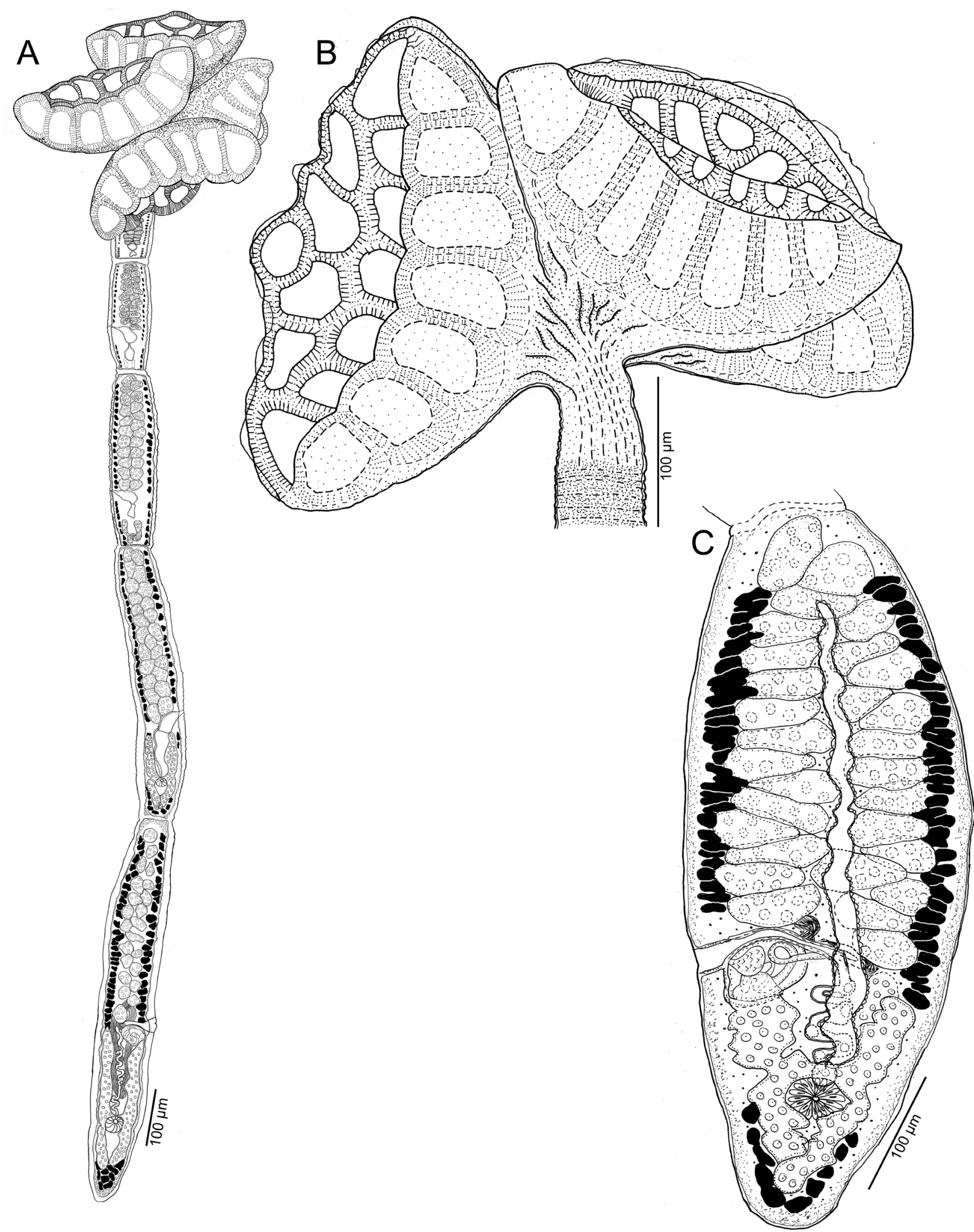

Fig. 2. Line drawings of Stillabothrium allisonae sp. n. from Fontitrygon margaritella (Compagno et Roberts) and Fontitrygon margarita (Günther). A - whole worm (Holotype ex F. margaritella; MNHN HEL758); B - scolex (Paratype ex F. margaritella; USNM 1474746); C - terminal proglottid (Paratype ex F. margarita; USNM 1474747).

or to middle of bothridia. Bothridia (Fig. 2B) usually contracted, varying in shape from shallowly-deltoid (Fig. 3B) to very shallowly-deltoid (Figs. 2A, 3A), facially loculated, $195-375(277 \pm 52 ; \mathrm{n}=17)$ long by $220-390(294 \pm 48$; $\mathrm{n}=17)$ wide; bothridial margins with thin rim of tissue. Bothridia (Fig. 2B) each with one anterior loculus, middle row of $4(n=17)$ loculi, and posterior row of $7(n=17)$ loculi longer than wide. Anterior-most loculus 28-47 (36 \pm ; 

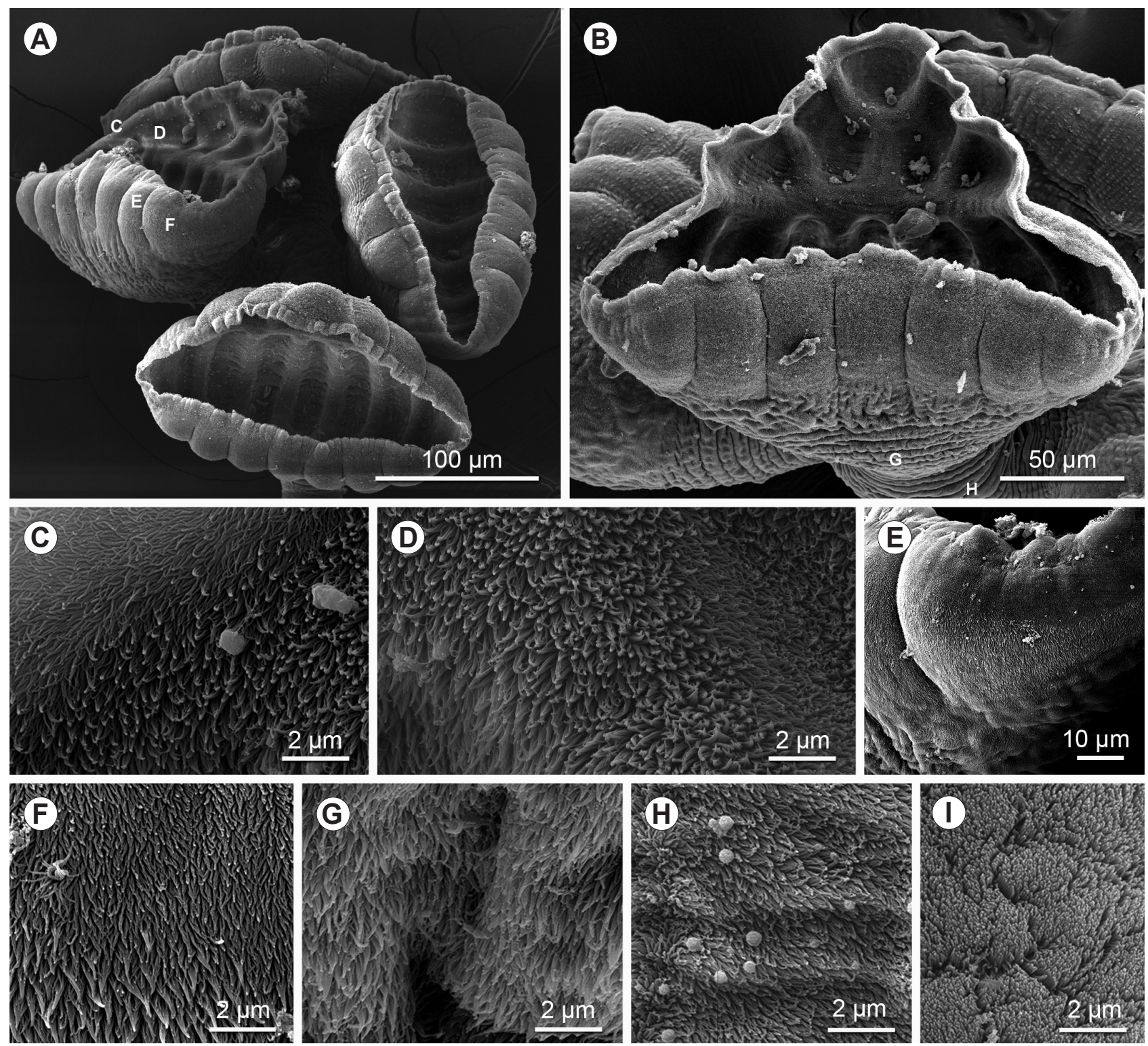

Fig. 3. Scanning electron micrographs of Stillabothrium allisonae sp. n. from Fontitrygon margaritella (Compagno et Roberts). A, B - scoleces, letters indicate locations of other micrographs; C - bothridial rim; D - distal bothridial surface of loculus in anterior region of bothridium; $\mathbf{E}$ - proximal bothridial surface and rim; $\mathbf{F}$ - proximal bothridial surface; $\mathbf{G}$ - distal portion of stalk; $\mathbf{H}$ - proximal portion of stalk; $\mathbf{I}$ - strobila.

$\mathrm{n}=17)$ long by $35-63(48 \pm 6 ; \mathrm{n}=17)$ wide. Longitudinal septa of posterior row not overlapping transverse septa of anterior region.

Loculi and septa (Fig. 3D) of distal bothridial surfaces bearing capilliform filitriches and coniform spinitriches. Bothridial rim bearing capilliform filitriches (Fig. 3C). Proximal bothridial surfaces away from rim (Fig. 3E) bearing acicular filitriches throughout bothridium. Posterior half of proximal bothridial surfaces (Fig. 3F) bearing patch of coniform spinitriches near, but not extending to, bothridial rim. Bothridial stalks bearing coniform spinitriches on distal portion (Fig. 3G) and only capilliform filitriches on proximal portion (Fig. 3H). Strobila (Fig. 3I) bearing capilliform filitriches only.

Strobila with $2-6(3.8 \pm 1.2 ; \mathrm{n}=17)$ proglottids wider than long followed by $4-8(5.6 \pm 1.2 ; \mathrm{n}=17)$ proglottids longer than wide. Strobila widest at terminal proglottid; terminal proglottid 480-970 $(675 \pm 122 ; \mathrm{n}=17)$ long by $80-210(123 \pm 40 ; n=17)$ wide; genital pore located $37-50 \%(44 \pm 5 ; n=15)$ of proglottid length from proglottid posterior margin. Immature proglottids 5-11 (7.9 \pm $1.8 ; \mathrm{n}=17)$ in number. Mature proglottids $1-2(1.6 \pm 0.5$; $\mathrm{n}=17)$ in number.

Testes $18-30(22 \pm 3 ; \mathrm{n}=16)$ in number, 1 layer deep, arranged in 2 columns (Fig. 2C); columns extending from anterior margin of proglottid to level of genital pore, 18-42 $(28 \pm 6 ; \mathrm{n}=14)$ long by $20-60(34 \pm 10 ; \mathrm{n}=13)$ wide. Vas deferens coiled, entering anterior margin of cirrus sac, extending from area anterior to ovarian isthmus to overlap several posterior-most testes (Fig. 2C), extensive in terminal mature proglottid. Cirrus sac thin-walled, oval, extending medially to midline or near midline of proglottid; cirrus 
sac in terminal proglottid 38-67 $(55 \pm 9 ; \mathrm{n}=12)$ long by 28-54 (42 $\pm 8 ; \mathrm{n}=12)$ wide. Cirrus spinitriches present.

Vagina (Fig. 2C) thick-walled, sinuous, slightly overlapping antero-medial portion of cirrus sac in some specimens, extending past midline of proglottid from ootype region to anterior margin of cirrus sac then laterally to open into genital atrium anterior to cirrus sac; vaginal sphincter absent. Seminal receptacle present. Ovary near posterior end of proglottid, H-shaped in frontal view, tetralobed in cross section; ovarian lobes somewhat asymmetrical; poral and aporal ovarian lobes in terminal proglottids 130-365 $(228 \pm 72 ; \mathrm{n}=15)$ and $152-435(253 \pm 79 ; \mathrm{n}=15)$ long, respectively. Maximum width of ovary 57-139 (85 \pm 24 ; $\mathrm{n}=15$ ). Ovarian isthmus at or near midpoint of ovary; poral lobe of ovary stopping $17-52(30 \pm 13 ; n=13)$ short of genital pore, stopping $8-45(22 \pm 20 ; n=3)$ short of cirrus sac, or overlapping its posterior portion. Mehlis' gland posterior to ovarian isthmus, 27-45 (34 \pm 7 ; $\mathrm{n}=11)$ long by $22-38(29 \pm 5 ; n=11)$ wide. Vitellarium follicular; vitelline follicles arranged in 1 dorsal and 1 ventral column on each side of proglottid; columns extending from near anterior to posterior margin of proglottid, interrupted by terminal genitalia, and interrupted to varying degrees by ovary (Fig. 2A,C). Uterus ventral, sacciform, extending from near isthmus of ovary to near anterior margin of proglottid.

Informal synonyms: New genus $3 \mathrm{sp}$. n. 1 of Healy et al. (2009), Caira et al. (2014), Ruhnke et al. (2015) and Marques and Caira (2016); Stillabothrium sp. n. 1 of Reyda et al. (2016).

Type host: Fontitrygon margaritella (Myliobatiformes: Dasyatidae).

Additional host: Fontitrygon margarita (Myliobatiformes: Dasyatidae).

Type locality: Atlantic Ocean off Mbour (14 $24^{\prime} 22^{\prime}$ N, $16^{\circ} 58^{\prime} 6^{\prime}$ 'W), Senegal (SE-125).

Additional localities: Atlantic Ocean off Joal $\left(14^{\circ} 10^{\prime} 30^{\prime \prime} \mathrm{N}, 16^{\circ} 51^{\prime} 12^{\prime \prime} \mathrm{W}\right)$ (SE-228, SE-229, SE-306, SE308), Djifere (135' $50^{\prime \prime} \mathrm{N}, 16^{\circ} 45^{\prime} 52^{\prime}$ 'W) (SE-232, SE-233, SE-241), and Kafountine $\left(12^{\circ} 55^{\prime} 41^{\prime \prime} \mathrm{N}, 16^{\circ} 45^{\prime} 10^{\prime \prime} \mathrm{W}\right)$ (SE262, SE-279), Senegal.

Site of infection: Spiral intestine.

Type material: Holotype MNHN No. HEL758; paratypes: MNHN No. HEL 757; IPCAS No. C-796; LRP Nos. 9894 9903, 9906-9911 (molecular vouchers) and 9904-9905 (SEM specimens); USNM Nos. 1474744-1474747.

E ty m o logy: This species is named in honour of Allison Hasson, best friend of E.A. Dedrick, for her support and friendship.

Remarks. Stillabothrium allisonae sp. n. can be distinguished from each of the seven previously reported species of Stillabothrium in the unique configuration of loculi on its bothridia (Fig. 1). In addition, S. allisonae differs from four of its congeners in its proglottid morphology. Stillabothrium allisonae has a proglottid morphology that is similar to that of $S$. ashleyae and $S$. davidcynthiaorum but can be distinguished from each of the latter species in the morphology of its bothridia because it lacks, rather than possesses, marginal septa in the posterior region (i.e. the posterior area of the bothridia with loculi that are longer than wide) of the bothridia. In addition, the anterior region of the bothridia of S. allisonae consists of a horizontal row of four loculi after the single anterior loculus, whereas in $S$. ashleyae and $S$. davidcynthiaorum it consists of a horizontal row of two loculi after the single anterior loculus. The bothridia of $S$. allisonae differs from those of $S$. campbelli in that they possess a greater number of loculi in the posterior region (7) than in the anterior region (5), and because none of their horizontal and vertical septa overlap one another, whereas they do prominently in S. campbelli, and in S. hyphantoseptum and $S$. amuletum.

Stillabothrium allisonae is further distinguished from S. campbelli in that its cirrus sac only extends medially to or near the midline of the proglottid instead of well past the midline (see fig. 6C in Reyda et al. 2016), as is the case with $S$. campbelli, and in that its uterus only extends as far posteriorly as the ovarian isthmus, instead of to the posterior margin of the proglottid, as it does in S. campbelli. Stillabothrium allisonae can also be distinguished from S. hyphantoseptum in its possession of more testes than the latter species (18-30 vs. 9-16). Stillabothrium allisonae further differs from $S$. hyphantoseptum and $S$. amuletum, and from $S$. cadenati and $S$. jeanfortiae in the that the loculi in the anterior region of the bothridium are not oriented in tandem, whereas they are in each of the four latter species.

Stillabothrium allisonae can also be distinguished from S. amuletum and S. cadenati in proglottid morphology. In S. allisonae the cirrus sac extends medially to or near the midline of the proglottid, whereas in S. cadenati and S. amuletum it extends well past the midline (fig. 12C in Reyda et al. 2016 and fig. 22 in Butler 1987, respectively); the vagina of $S$. allisonae is not recurved, whereas it is in $S$. cadenati and $S$. amuletum; the genital atrium of $S$. allisonae lacks the convoluted walls and muscular appearance that characterises the genital atrium of $S$. cadenati and $S$. amuletum; the vitellarium of $S$. allisonae is restricted to varying degrees by the ovary whereas it is not in $S$. cadenati and S. amuletum. Stillabothrium allisonae also possesses more testes than $S$. cadenati (18-30 vs. 7-13).

Stillabothrium charlotteae Iwanyckyj, Dedrick et Reyda, sp. n.

Figs. 1, 4, 5

ZooBank number:

urn:1sid:zoobank.org:act:3A504890-8EE0-446D-8489-678C46C6FB64

Description (based on whole mounts of 15 complete mature worms, two incomplete worms and three scoleces prepared for SEM): Worms (Fig. 4A) euapolytic, acraspedote, $1.71-3.70 \mathrm{~mm}(0.26 \pm 0.62 ; \mathrm{n}=15)$ long, greatest width $330-526(412 \pm 54 ; \mathrm{n}=17)$ at level of scolex; 7-12 $(8.9 \pm 2 ; n=14)$ proglottids per worm. Cephalic peduncle lacking; darkly staining germinative zone present.

Scolex (Fig. 4B) consisting of scolex proper bearing four stalked bothridia. Stalks 45-115 $(87 \pm 21 ; \mathrm{n}=17)$ long by $55-100(72 \pm 10 ; \mathrm{n}=17)$ wide, attached slightly posterior to middle of bothridia. Bothridia (Fig. 4B) somewhat contracted posteriorly, varying in shape from deeply 


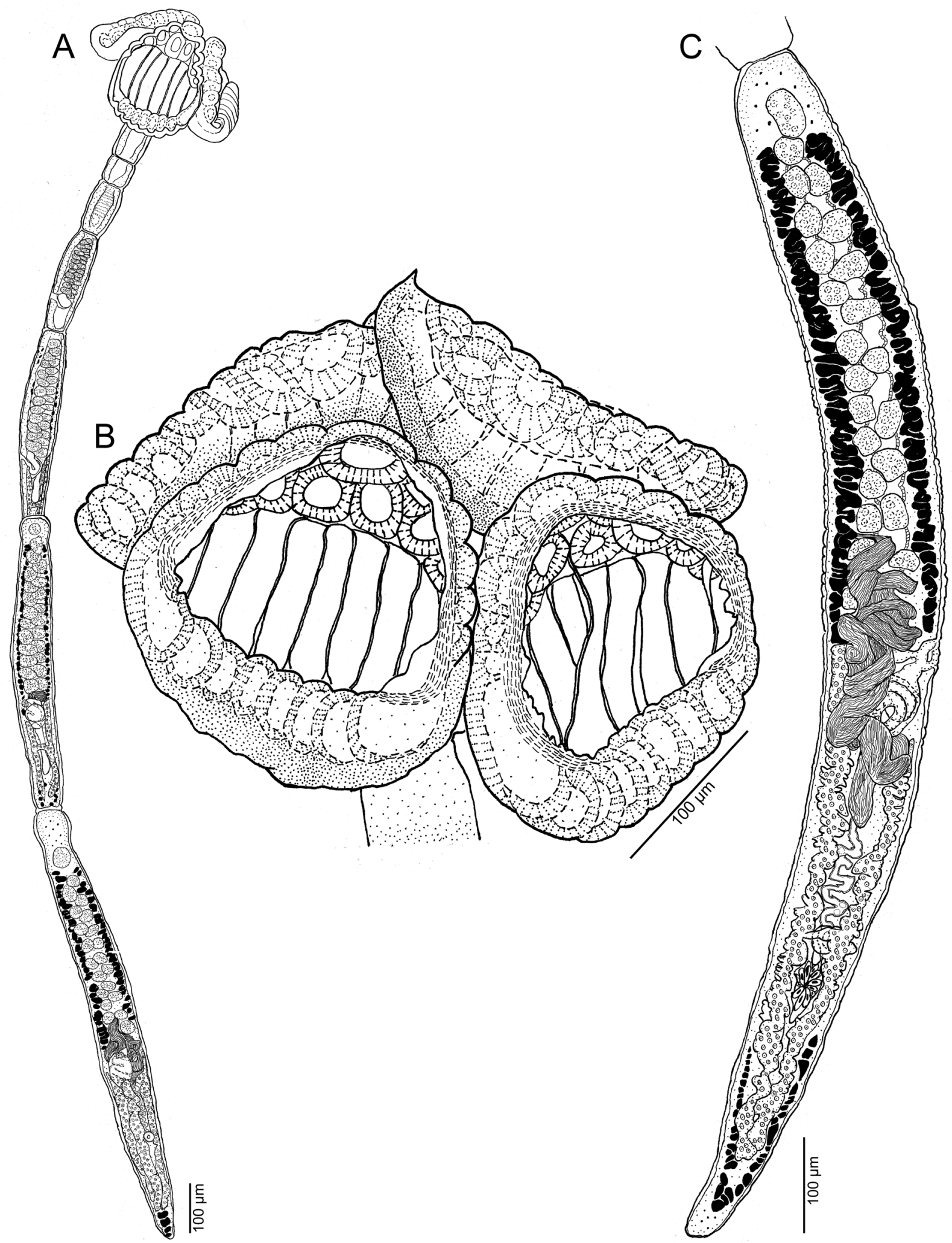

Fig. 4. Line drawings of Stillabothrium charlotteae sp. n. from Fontitrygon margarita (Günther). A - whole worm (holotype; MNHN HEL760); B - scolex (paratype; USNM 1474750); C - terminal proglottid (paratype; LRP 9924).

deltoid (Fig. 4A) to finely-deltoid (Fig. 4B) to broadly-deltoid, facially loculated, 215-320 (255 $\pm 32 ; \mathrm{n}=17)$ long by $215-284(249 \pm 20 ; n=17)$ wide; bothridial margins with thin rim of tissue. Bothridia (Fig. 4B) each with one anterior loculus, middle row of two $(n=14)$ loculi, $4-5$
$(4.9 \pm 0.3 ; \mathrm{n}=12)$ marginal loculi, and posterior row of $9(n=16)$ loculi longer than wide. Marginal loculi extend from anterior region of bothridia to anterior portion of posterior region of bothridium. Anterior-most loculus 28-40 $(33 \pm 4 ; \mathrm{n}=15)$ long by $35-57(48 \pm 6 ; \mathrm{n}=16)$ wide. 

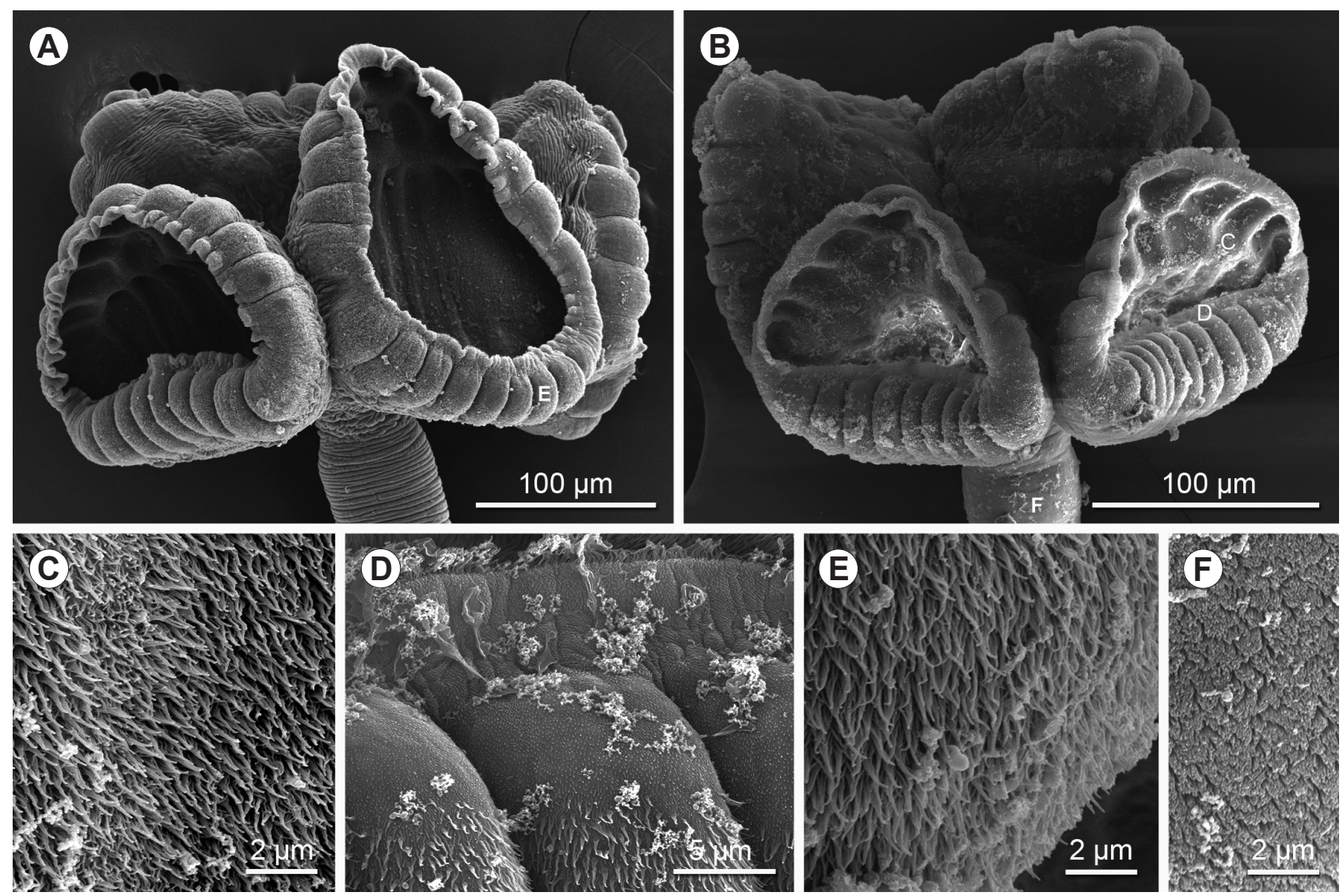

Fig. 5. Scanning electron micrographs of Stillabothrium charlotteae sp. n. from Fontitrygon margaritella (Compagno et Roberts). A, B, - scoleces, letters indicate locations of other icrographs; $\mathbf{C}$-distal bothridial surface of loculus in anterior region of bothridium; D - proximal surface near bothridial rim; $\mathbf{E}$ - proximal bothridial surface; $\mathbf{F}$ - strobila.

Longitudinal septa of posterior region not overlapping transverse septa of anterior region, thinner than those of anterior region.

Loculi and septa (Fig. 5C) of distal bothridial surfaces bearing capilliform filitriches and coniform spinitriches. Proximal bothridial rim (Fig. 5D) bearing capilliform filitriches. Proximal bothridial surfaces away from rim bearing acicular filitriches throughout bothridium and, in posterior half (Fig. 5E), patch of coniform spinitriches. Bothridial stalks not observed with SEM. Strobila (Fig. 5F) bearing capilliform filitriches only.

Strobila with $1-5(3.5 \pm 1.5 ; \mathrm{n}=14)$ proglottids that are wider than long followed by 4-7 $(5.3 \pm 0.9 ; \mathrm{n}=14)$ proglottids that are longer than wide. Strobila widest at terminal proglottid; terminal proglottid 590-1,170 (903 \pm 182 ; n $=16)$ long by $85-150(115 \pm 16 ; \mathrm{n}=16)$ wide; genital pore located $39-49 \%(44 \pm 3 ; n=16)$ of proglottid length from proglottid posterior margin. Immature proglottids 4-10 $(7.1 \pm 1.7 ; \mathrm{n}=17)$ in number. Mature proglottids $1-2(1.7$ $\pm 0.5 ; \mathrm{n}=15)$ in number.

Testes $22-26(24 \pm 2 ; \mathrm{n}=17)$ in number, 1 layer deep, arranged in 2 columns (Fig. 4C); columns extending from anterior margin of proglottid to level of genital pore, $18-55(31 \pm 10 ; \mathrm{n}=17)$ long by $21-43(33 \pm 7 ; \mathrm{n}=17)$ wide. Vas deferens coiled, entering anterior margin of cirrus sac, extending from area anterior to ovarian isthmus to overlap several posterior-most testes (Fig. 4C). Cirrus sac thin-walled, oval, extending medially past midline of proglottid; cirrus sac in terminal proglottid 52-88 (71 \pm $11 ; \mathrm{n}=15)$ long by $42-65(54 \pm 9 ; \mathrm{n}=15)$ wide. Cirrus spinitriches present.

Vagina (Fig. 4C) thick-walled, sinuous (Fig. 4C), slightly overlapping antero-medial portion of cirrus sac in some specimens, extending past midline of proglottid from ootype region to anterior margin of cirrus sac then laterally to open into genital atrium anterior to cirrus sac, vaginal sphincter absent. Seminal receptacle present. Ovary near posterior end of proglottid, H-shaped in frontal view, tetralobed in cross section; ovarian lobes somewhat asymmetrical; poral and aporal ovarian lobes in terminal proglottids $125-420(281 \pm 80 ; \mathrm{n}=17)$ and 137-438 (319 \pm $102 ; n=17)$ long, respectively. Maximum width of ovary $65-90(79 \pm 9 ; n=17)$. Ovarian isthmus at or near midpoint of ovary; poral lobe of ovary stopping 10-90 (52 \pm $21 ; \mathrm{n}=17$ ) short of genital pore, somewhat overlapping posterior portion of cirrus sac. Mehlis' gland posterior to ovarian isthmus, $22-65(42 \pm 13 ; \mathrm{n}=14)$ long by $22-36$ $(29 \pm 5 ; \mathrm{n}=14)$ wide. Vitellarium follicular; vitelline follicles arranged in 1 dorsal and 1 ventral column on each side of proglottid; columns extending from near anterior to posterior margin of proglottid, interrupted by terminal genitalia, and interrupted to varying degrees by ovary (Fig. 4A,C). Uterus ventral, sacciform, extending from near isthmus of ovary to near anterior margin of proglottid. 
Informal synonyms: New genus 3 sp. n. 2 of Healy et al. (2009), Caira et al. (2014), Ruhnke et al. (2015), and Marques and Caira (2016); Stillabothrium sp. n. 2 of Reyda et al. (2016).

Type host: Fontitrygon margarita (Dasyatidae: Myliobatiformes).

Additional host: Fontitrygon margaritella (Dasyatidae: Myliobatiformes).

Type 1ocality: Atlantic Ocean off Djifere $\left(13^{\circ} 55^{\prime} 50^{\prime} \mathrm{N}\right.$, $\left.16^{\circ} 45^{\prime} 52^{\prime \prime} \mathrm{W}\right)$, Senegal (SE-241).

Additional localities: Atlantic Ocean off Mbour $\left(14^{\circ} 24^{\prime} 22^{\prime \prime} \mathrm{N}, 1^{\circ} 58^{\prime} 6^{\prime} \mathrm{W}\right)$ (SE-125), Joal $\left(14^{\circ} 10^{\prime} 30^{\prime \prime} \mathrm{N}\right.$, $\left.16^{\circ} 51^{\prime} 12^{\prime \prime} \mathrm{W}\right)$ (SE-228), and Kafountine $\left(12^{\circ} 55^{\prime} 41^{\prime \prime} \mathrm{N}\right.$, $\left.16^{\circ} 45^{\prime} 10^{\prime \prime} \mathrm{W}\right)(\mathrm{SE}-262, \mathrm{SE}-279)$, Senegal.

Site of infection: Spiral intestine.

Type material: Holotype MNHN No. HEL760; paratypes: MNHN No. HEL 759; IPCAS No. C-797; LRP Nos. 9920 9929, 9933 (molecular voucher) and 9930-9932 (SEM specimens); USNM Nos. 1474748-1474751.

Etymology: This species is named in honour of Charlotte Winter, grandmother of E.K. Iwanyckyj, for her support of her granddaughter's studies and journey through life.

Remarks. Stillabothrium charlotteae sp. n. can be distinguished from each of its eight congeners in the unique configuration of loculi on its bothridia (Fig. 1). It can also be distinguished from six of its eight congeners in its proglottid morphology. The pattern of loculi on the bothridia of $S$. charlotteae differentiate it from $S$. ashleyae and $S$. davidcynthiaorum in two aspects. First, the bothridia of Stillabothrium charlotteae bear a row of four loculi immediately behind the anterior-most loculus, but those of $S$. ashleyae and $S$. davidcynthiaorum bear a row of only two loculi. Second, the marginal loculi of $S$. charlotteae are positioned differently than those of $S$. ashleyae and $S$. davidcynthiaorum. Whereas the marginal loculi of $S$. charlotteae span the anterior half of the bothridia, they are located in the posterior half of the bothridia of the latter two species. Stillabothrium charlotteae is further distinguished from $S$. davidcynthiaorum in its possession of more testes than the latter species (22-26 vs. 11-21).

The presence of marginal loculi of $S$. charlotteae are sufficient to differentiate it from each of the other six species of Stillabothrium ( $S$. campbelli, S. hyphantoseptum, S. cadenati, S. amuletum, S. jeanfortiae and $S$. allisonae) which all lack marginal loculi, but there are additional respective differences between it and the other six species. Stillabothrium charlotteae can be clearly distinguished from S. campbelli, S. hyphantoseptum, S. cadenati, S. amuletum and $S$. jeanfortiae in that the anterior region of the bothridium in each of the latter five species consists of loculi oriented in tandem, unlike those of $S$. charlotteae.

Stillabothrium charlotteae is further distinguished from S. campbelli, S. hyphantoseptum and S. amuletum in that none of its septa overlap one another, whereas they do so prominently in each of the latter three species. Also, $S$. charlotteae possesses more testes than $S$. campbelli and S. hyphantoseptum (22-26 vs. 12-19 and 9-16, respectively) and has a less extensive uterus than that of $S$. camp- belli (i.e. only extending as far posteriorly as the ovarian isthmus in S. charlotteae vs. extending to the posterior margin of the proglottid in S. campbelli). The proglottid morphology of $S$. charlotteae differs from that of $S$. amuletum and from $S$. cadenati in several aspects. The vagina of $S$. charlotteae is not recurved, whereas it is in $S$. cadenati and $S$. amuletum; the genital atrium of $S$. charlotteae lacks the convoluted walls and muscular appearance that characterises those of $S$. cadenati and $S$. amuletum; the vitellarium of $S$. charlotteae is restricted to varying degrees by the ovary whereas they are not in $S$. cadenati and $S$. amuletum.

Stillabothrium charlotteae and S. allisonae overlap geographically, use the same two stingray species as definitive hosts, and possess relatively similar proglottid morphologies. The two species can be readily distinguished, however, in several aspects of the bothridial morphology and in the extent of their cirrus sacs. Stillabothrium charlotteae differs from $S$. allisonae in its possession of a posterior row of nine, rather than seven, loculi and also in its possession, rather than lack, of a series of four marginal loculi in tandem on each side of the bothridium.

These differences are less apparent in specimens in which the bothridia are contracted; in such specimens, the number of septa that connect to the anterior-most loculus can be used to distinguish the two species (three in S. charlotteae vs. one in S. allisonae; see Fig. 1). The septa in $S$. charlotteae vary in width, with the longitudinal septa in the posterior region of bothridia being thinner than those septa in the anterior region (Fig. 4B), whereas the septa in $S$. allisonae are more uniform in width throughout the bothridium (Fig. 2B). Finally, the cirrus sac of $S$. charlotteae is more extensive than that of $S$. allisonae in that it extends medially past the midline of the proglottid in the former species but only extends to or near the midline in the latter species.

\section{DISCUSSION}

Reyda et al. (2016) emphasised the extensive variation in the arrangement of facial loculi of the bothridia of the seven species of Stillabothrium characterised in that study. The scope of variation in the arrangement of facial loculi is expanded here with the addition of Stillabothrium allisonae and Stillabothrium charlotteae, and is depicted in the context of the phylogeny in Fig. 1. Somewhat surprisingly, but in line with the results of Reyda et al. (2016), there are no explicit phylogenetic patterns of variation in the arrangement of facial loculi with respect to the phylogeny. For example, those species with overlapping septa (i.e. Stillabothrium amuletum, Stillabothrium hyphantoseptum, Stillabothrium campbelli, and to some extent, Stillabothrium cadenati) do not form a single clade to the exclusion of other species, nor do those species with marginal loculi (Stillabothrium ashleyae, Stillabothrium davidcynthiaorum and $S$. charlotteae) nor those species with loculi oriented in tandem ( $S$. campbelli, S. hyphantoseptum, $S$. cadenati, $S$. amuletum and Stillabothrium jeanfortiae). Instead, both Clade 1 and Clade 2 possess species with each of those features. Given the anticipated additional species diversity of Stillabothrium (see below), future studies may 
reveal phylogenetic patterns of morphological variation that remain unclear at present.

In addition to scolex morphological diversity, species of Stillabothrium vary extensively in their geographic distribution. Species of Stillabothrium occur in the Eastern and Western Hemispheres, specifically the Indo-Pacific and the eastern Atlantic. Some general patterns of geographic variation among species of Stillabothrium are evident with respect to the phylogeny. Curiously, both clades include species of Stillabothrium from northern Australia (S. amuletum in Clade 2 and $S$. jeanfortiae in Clade 1). The other biogeographic areas represented by the species in the phylogeny are restricted to either Clade 1 or Clade 2. All three species of Stillabothrium from the eastern Atlantic ( $S$. cadenati, $S$. charlotteae and $S$. allisonae) are within Clade 2, and all four species from coastal Borneo (S. campbelli, S. hyphantoseptum, $S$. davidcynthiaorum and $S$. ashleyae) occur within Clade 1.

The pattern of host associations evident from the phylogeny of species of Stillabothrium is the same as that found by Reyda et al. (2016); a diversity of batoid host species, most of which are dasyatids, are represented in both clades. Clade 1 includes species of Stillabothrium from myliobatiform genera from the Dasyatidae Jordan including Fontitrygon Last, Naylor et Manjaji-Matsumoto, Himantura Müller et Henle and Maculabatis Last, Naylor et Manjaji-Matsumoto. A single species from Clade 1, $S$. cadenati, parasitises the rhinopristiform Rhinobatos rhinobatos (Linnaeus). Likewise, in Clade 2, most of the host associations are with myliobatiform genera of the Dasyatidae including Maculabatis, Brevitrygon Last, Naylor et Manjaji-Matsumoto, and Telatrygon Last, Naylor et Manjaji-Matsumoto, but there is a single host association with the rhinopristiform Glaucostegus typus (Bennett). Given that most of the known species of Stillabothrium parasitise species of dasyatids, and given the high diversity of that elasmobranch family (see Last et al. 2016), we predict continued discovery of new Stillabothrium species as more dasyatids are examined, especially those species that occur in the eastern Atlantic and Indo-Pacific, i.e. the known distribution of the species Stillabothrium reported to date.

Stillabothrium allisonae and S. charlotteae are sister species with a somewhat relaxed level of host specificity in that they parasitise the same two host species, Fontitrygon margaritella and Fontitrygon margarita. Given that this somewhat relaxed level of host specificity is unusual relative to other rhinebothriidean cestodes (e.g. Ruhnke et al. 2015) which, for the most part, exhibit a strict or oioxenous level of host specificity (sensu Euzet and Combes 1980), one focus of this study was comparison of putatively conspecific specimens from their respective hosts. Morphological examination of the three specimens of $S$. charlotteae from $F$. margaritella and the 14 specimens of $S$. charlotteae from $F$. margarita did not reveal any morphological differences between specimens from each host species. Likewise, the 12 specimens of $S$. allisonae from
F. margaritella and five specimens of S. allisonae from $F$. margarita that were measured did not discernibly differ in their morphology. The conspecificity of specimens of $S$. allisonae from $F$. margaritella and F. margarita was further supported by the results of the molecular analyses in that one of the two specimens from $F$. margarita had an identical sequence to five of the six specimens from F. margaritella (see Results and Fig. 1) for the D1-D3 region of 28S rDNA gene. It should be noted that Reyda et al. (2016) also found a somewhat relaxed level of host specificity for two of the seven species of Stillabothrium examined in that study.

The two host species $F$. margaritella and F. margarita were found to be sister species in the analysis by Last et al. (2016). This scenario in which two sister species of cestode parasitise two sister species of elasmobranch hosts is of particular interest because it raises questions about patterns of speciation and adaptive radiation. In addition, there are relatively few parallel scenarios that have been documented among elamobranch cestodes. One such scenario exists in the rhinebothriidean genus Anthocephalum Linton, 1890, in which the sister species Anthocephalum healyae Ruhnke, Caira et Cox, 2015 and Anthocephalum odonnellae Ruhnke, Caira et Cox, 2015 parasitise two closely related species of Neotrygon Castelnau (Ruhnke et al. 2015). Given the relatively short list of cases of sister species of elasmobranch cestodes parasitising sister species of elasmobranchs, the host-parasite system characterised in this study consisting of two species of Fontitrygon and two species of Stillabothrium would make an ideal focus for future studies of coevolution. The improved taxonomic framework for Stillabothrium that we have provided here make this an appealing host-parasite system for future studies of host and parasite evolution to explore.

Acknowledgements. We are grateful to Janine Caira (University of Connecticut, Storrs, Connecticut) and Kirsten Jensen (University of Kansas, Lawrence, Kansas) for their efforts to collect the specimens that were utilised in this study during multiple field trips to Senegal. Carrie Fyler and Kenneth Barber also assisted with that field work, as did Claire Healy, who generated some of the SEM images used in this study. We thank Andrew Haslach (West Virginia State University) for providing the DNA sequence data for $S$. allisonae and S. charlotteae. Kaylee Herzog (University of Kansas, Lawrence, Kansas) provided helpful comments about these species. This work was partially supported with funds from National Science Foundation (NSF) grants, Partnership for Enhancing Expertise in Taxonomy (PEET) grant (DEB No. 0118882), a Planetary Biodiversity Inventory (PBI) collaborative grant (DEB Nos. 0818696 and 0818823), and a Field Stations and Marine Laboratories (FSML) grant (DBI No. 1034744). Partial funding for this study was also provided by grants from the State University of New York College at Oneonta Foundation, Inc., the SUNY Oneonta Alumni Association, and the SUNY Oneonta Research Foundation. This work was performed in part at the Biosciences Electron Microscopy Facility of the University of Connecticut (NSF grant No. 1126100). Any opinions, findings, and conclusions or recommendations here are those of the authors and do not necessarily reflect the views of the National Science Foundation. 


\section{REFERENCES}

ButLer S.A. 1987: Taxonomy of some tetraphyllidean cestodes from elasmobranch fishes. Aust. J. Zool. 35: 343-371.

Caira J.N., Healy C.J., Marques F.P.L., Jensen K. 2017: Three new genera of rhinebothriidean cestodes from stingrays in Southeast Asia. Folia Parasitol. 64: 008.

CAIRA J.N., Jensen K. 2017: Planetary Biodiversity Inventory (2008-2017): Tapeworms from Vertebrate Bowels of the Earth University of Kansas, Natural History Museum, Special Publication No. 25, Lawrence, Kansas, USA, 464 pp.

Caira J.N., Jensen K., Barbeau, E. 2012: Global Cestode Database. World Wide Web electronic publication. University of Connecticut, Storrs, CT, USA Available from: http://www.tapewormdb.uconn.edu (Accessed 26 February 2018)

Caira J.N., Jensen K., Waeschenbach A., Olson P.D., LitTLEWOOD D.T.J. 2014: Orders out of chaos - molecular phylogenetics reveals the complexity of shark and stingray tapeworm relationships. Int. J. Parasitol. 44: 55-73.

Chervy L. 2009: Unified terminology for cestode microtriches: a proposal from the International Workshops on Cestode Systematics in 2002-2008. Folia Parasitol. 56: 199-230.

ClOpton R.E. 2004: Standard nomenclature and metrics of plane shapes for use in gregarine taxonomy. Comp. Parasitol. 71: 130140.

Euzet L., Combes C. 1980: Les problémes de l'espéce chez les animaus parasites. Mem. Soc. Zool. France. 3: 239-285.

Healy C.J., Caira J.N., Jensen K., Webster B.L., Littlewood, D.T.J. 2009: Proposal for a new tapeworm order, Rhinebothriidea. Int. J. Parasitol. 39: 497-511.

Last P.R., Naylor G.J.P., Manjaji-Matsumoto B. M. 2016: A revised classification of the family Dasyatidae (Chondrichthyes: Myliobatiformes) based on new morphological and molecular insights. Zootaxa. 4139: 345-368.
Marques F.P.L., Caira J. N. 2016: Pararhinebothroides - neither the sister-taxon of Rhinebothroides nor a valid genus. J. Parasitol. 102: 249-259.

Naylor G., Caira J.N., Jensen K., Rosana K.A., Straube N., LAKNER C., 2012a: Elasmobranch phylogeny: a mitochondrial estimate based on 595 species. In: J.C. Carrier, J.A. Musick and M.R. Heithaus (Eds.), Biology of Sharks and Their Relatives. CRC Press, Boca Raton, pp. 31-56.

Naylor G., Caira J.N., Jensen K., Rosana K.A., White W.T. 2012b: A DNA sequence-based approach to the identification of shark and ray species and its implications for global elasmobranch diversity and parasitology. Bull. Am. Mus. Nat. Hist. 367: 215-240.

Pleijel R., Jondelius U., Norlinder E., Nygeren A., Oxelman B., Schander C., Sundberg P., Thollesson M. 2008: Phylogenies without roots? A plea for the use of vouchers in molecular phylogenetic studies. Mol. Phylogenet. Evol. 48: 369-371.

Reyda F.B., Healy C.J., Haslach A.R., Ruhnke T.R., Aprill T.L., Bergman M.P., Daigler A.L., Dedrick E.A., Delgado I., Forti K.S., Herzog K.S., Russell R.S., Willsey D.D. 2016: A new genus of rhinebothriidean cestodes from batoid elasmobranchs, with the description of five new species and transfer of two species. Folia Parasitol. 63: 038.

RonQuist F., Huelsenbeck J.P. 2003: MRBAYES 3: Bayesian phylogenetic inference under mixed models. Bioinformatics 19: 1572-1574.

Ruhnke T.R., Caira J.N., Cox A. 2015: The cestode order Rhinebothriidea no longer family-less: a molecular phylogenetic investigation with erection of two new families and description of eight new species of Anthocephalum. Zootaxa 3904: 051-081.

SwOFFORD D.L. 2000: PAUP*: Phylogenetic Analysis Using Parsimony, Version 4.0b, Sinauer Assoc., Sunderland, Massachusetts.

Cite this article as: Dedrick E.A., Reyda F.B., Iwanyckyj E.K., Ruhnke T.R. 2018: Two new species of Stillabothrium (Cestoda: Rhinebothriidea) from stingrays of the genus Fontitrygon from Senegal. Folia Parasitol. 65: 014. 